\title{
DISASTER CHALLENGES IN TOURISM INDUSTRY AND LOCAL COMMUNITIES IN THE ANNAPURNA CONSERVATION AREA
}

\author{
Balaram Raya \\ Associate Professor, Department of Geography, Sanothimi Campus, Bhaktapur, TU. \\ Corresponding author: balaram.raya@foe.tu.edu.np
}

\begin{abstract}
Tourism is providing various opportunities to the stakeholders from local residents to national government in the country. Tourism sector has contributed $10.4 \%$ of global GDP and $9.9 \%$ of total employment in 2017 while $4.3 \%$ GDP and $3.5 \%$ of total employment of Nepal depended on tourism in 2014. Annapurna Circuit comprises most popular trekking route in the world with 22 feasible trekking sub-routes. The tourist flow has steadily increased from beginning to the recent time except for a few years in the insurgency period. The arrival of tourists in the Annapurna region has significantly decreased due to Snow Storm in 2014 and Earthquake in 2015. These natural disasters have also severely damaged the infrastructures of tourism industry. As a result, tourism sector has been unable to continue job and create regular income regularly to the local people of ACA as well as high Mountain areas of Nepal in a consecutive years. It is necessary to cope with the problem by following resilience strategy to recover tourism in the future.
\end{abstract}

Keywords: tourism - GDP - livelihood - snow strom - earthquake.

\section{INTRODUCTION}

Tourism is the most potential growing sector in Nepalese economy (Sharma 2012) as well as world's largest economic sector which provides jobs, drives exports, and generates prosperity across the world. An annual analysis of the global wider indirect and induced economic impact of travel and tourism sector accounts for $10.4 \%$ of global gross domestic product (GDP) and 313 million (9.9\%) of total employment according to the record of 2017 (WTTC 2018a). Likewise, the total contribution of this sector has been US\$281.6 billion (8.9\%) in GDP and 49.9 million jobs $(7.5 \%)$ in total employment according to the record of 2017 in South Asia (WTTC 2018b). 
Similarly, travel and tourism have significantly contributed in the Nepalese economy, and visitors are steadily increasing except for the earthquakes struck year 2015. According to Department of Immigration record, arrival of tourists in Nepal was nearly 800,000 in 2013 (MoCTCA 2016). It could not figure out the exact contribution in GDP due to absence of tourism record. Nevertheless, the World Travel and Tourism Council (WTTC) report-2015 reported national GDP by $4.3 \%$, which reflects direct contribution of this sector in the year 2014.

The development of tourism has started since the decade of 1950s in Nepal when government had granted the permission for outsiders (Shrestha \& Shrestha 2012). A little over 4000 visitors had primarily traveled in Kathmandu valley in 1961 while mountain trekking began first in 1966 (Nepal 2000). Unique geographical features, rich biodiversity and cultural heritage of the Himalayan region of Nepal have always attracted trekkers, mountaineers, adventurers and pleasure seeking tourists from all over the world, so these factors are playing significant role in the growth of tourism industry. The flow of tourists had steadily grown in mountain protected areas. Nearly $23 \%$ tourists had visited mainly for the purpose of trekking and mountaineering in Everest, Annapurna and Langtang regions in 1996 (HMG 1996 cited in Nepal 2000). The figure reached 26\% in 2009 (Sharma 2012). Meanwhile, local people particularly those who are living in and around Sagarmatha National Park and Annapurna Conservation Area (ACA) have received substantial income and employment benefits from tourism (Wells 1994).

Unfortunately, the earthquake incidents of April 25 and May 12, 2015 (with the magnitude of $7.8 \& 7.3$ respectively) with several aftershocks caused about 9,000 human fatalities and destroyed over 500,000 building structures. The estimated cost of economic impact caused by this disaster has remained around NPR 700 billion (NPC 2015). There was huge destruction of historical and commercial structures due to unreinforced masonry construction (Miyamoto \& Gilani 2017). At the same time, tourism sector has been severely affected as a result of the damage of physical environment in the 14 districts affected from earthquake 2015. The country has suffered from major economic loss in the next two to three years. Consequently, tourist arrival and its revenue will be directly affected over a couple of years. Other nations also have similar experiences in taking several years to recover in tourist arrivals. It can be estimated that Nepalese tourism sector 
will reduce in size about $40 \%$ in tourists' arrival annually up to the next years (NPC 2015).

Nepal not only suffered from earthquake in 2015, but also suffered from blizzards and avalanches in the year 2014 in Annapurna Circuit caused by several natural disasters including the creation of landslide blockage dam along Marsyangdi river at lower Pisang village in Manang district, which caused risk to the settlement and trekking trail (MoHA \& ICIMOD 2015). This situation has not only disturbed the tourism industry of Nepal but also caused direct impacts in the life of the people engaged in tourism activity. After these natural disasters, the loss and damage in human life as well as in the infrastructures were significant. Likewise, tourism dependent rural economy and livelihood has been severely affected; and there was loss in revenue in the country. But, there is lack of detailed information on the impacts of natural hazards to the tourism industry in Annapurna Circuit. The impact of the earthquake and avalanche on tourism and local people's livelihood could be the important issue in the Annapurna region. Hence, the present study attempted to analyze the disturbances on tourism industry and livelihood of local people due to the natural disasters in the Annapurna Conservation Area.

\section{MATERIALS AND METHODS}

This study is mainly based on secondary sources. Available papers, reports and digital information published by various institutions working in the sectors of natural disaster, travel and tourism have been used as the source of data. The study area is Annapurna Conservation Area which is the first declared and largest conservation area in Nepal (Figure 1).

It covers an area of $7,629 \mathrm{~km}^{2}$ with the elevation ranging from $950 \mathrm{~m}$ in Madi valley to $8091 \mathrm{~m}$ in Annapurna I above mean sea level. According to the population census 2011, there are 91,688 people of various cultural groups in this area (CBS 2012). The world's deepest Kaligandaki river valley and the fresh water Tilicho Lake located at the highest altitude are also in the area. Administratively, ACA is spread over five districts: Kaski, Lamjung, Manang, Mustang and Myagdi (DNPWC 2010); and it has 15 Rural Municipalities (DNPWC 2018). Annapurna region has been divided into two unique geographical places. Manang and Mustang districts are situated in the trans-Himalayas with driest cold climate, and the remaining districts are in the windward of Annapurna range with wet climatic zone 
of Nepal. Nepal's highest annual average precipitation is recorded with $5402.8 \mathrm{~mm}$ in Lumle area of Kaski district, while Lomanthan (in north from Annapurna region, leeward side) in same range receives lowest amount of rainfall with $143.6 \mathrm{~mm}$ (Practical Action 2009 \& MoHA \& DPNet 2009).

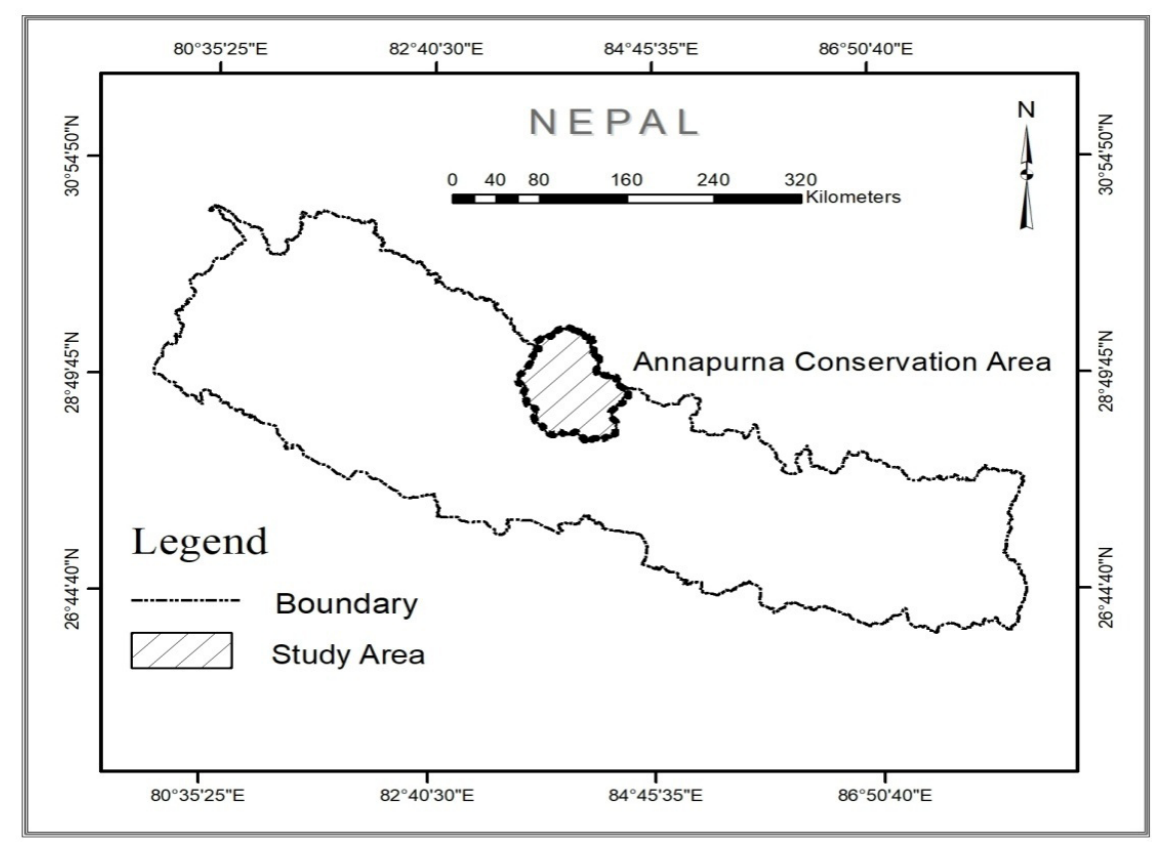

Figure 1: Location of Annapurna Conservation Area.

\section{RESULTS AND DISCUSSION}

\section{Trend of tourist arrival}

ACA is one of the most amazing ecotourism and the worldclass trekking destinations in Nepal. This has been possible as a result of integration among tourism, protected area and local communities (Bajracharya 2011). There are 22 trekking routes such as the GhorepaniPunhill trek, the Annapurna Circuit, the Ghandruk Trek, the Annapurna Base Camp-cum-Annapurna Sanctuary Trek (often called ABC), the Ghandruk-Ghorepani Circuit \& the Sikles Eco-Trek etc. Ten of these are the most entertaining circuits with tourism facilities mostly managed by the community at different places. Moreover, the panoramic view of Annapurna Himalayan Range, traditional offering with Tibetan culture and change in nature diversity along with the cultural variations within the short travel distance are the most important attractions for all visitors 
and travelers (NTNC 2017). In addition, other principal features luring the visitors include terrace settlements, Monasteries dated back to centuries, Muktinath temple, Tilicho lake, Damodar Kunda and lunar landscape of the trans-Himalayan ranges which are rarely available in the world.

ACA serves all types of tourists including adventurers, pleasure seekers and holiday makers from 137 countries mainly the USA, China and France. However, the major inducement to visitors in ACA is still the nature hiking and trekking (NTNC 2009). Hence, ACA is the most visited destination of international travelers in Nepal accounting for almost $60 \%$ of country's total trekkers in 2009 (MoFSC 2012 \& Sharma 2012). As a result, the number of trekkers visiting ACA has been increasing with an exception in the period of the Maoist insurgency from 2002 to 2006. But the visitors' number increased after the Comprehensive Peace Agreement. Mountaineering and trekking activities are still seasonal as these activities are not found in cold winter and rainy season. October is the peak trekking month followed by November, March and April. Tourists from all countries except India are visiting the Annapurna Circuit for trekking purpose. ACAP Pokhara Office reported that almost $90 \%$ of Indian tourists are religious tourists coming to Muktinath for pilgrimage in this region.

Information related to the trekkers of Annapurna Circuit is available from 1989. Tourist flow in ACA is sharply increasing to date except for some years. Nonetheless, the number of tourists has been hopeless in some years like 2001, 2002, 2005 and 2015. The increment of tourist flow varies from year to year (Figure 2).

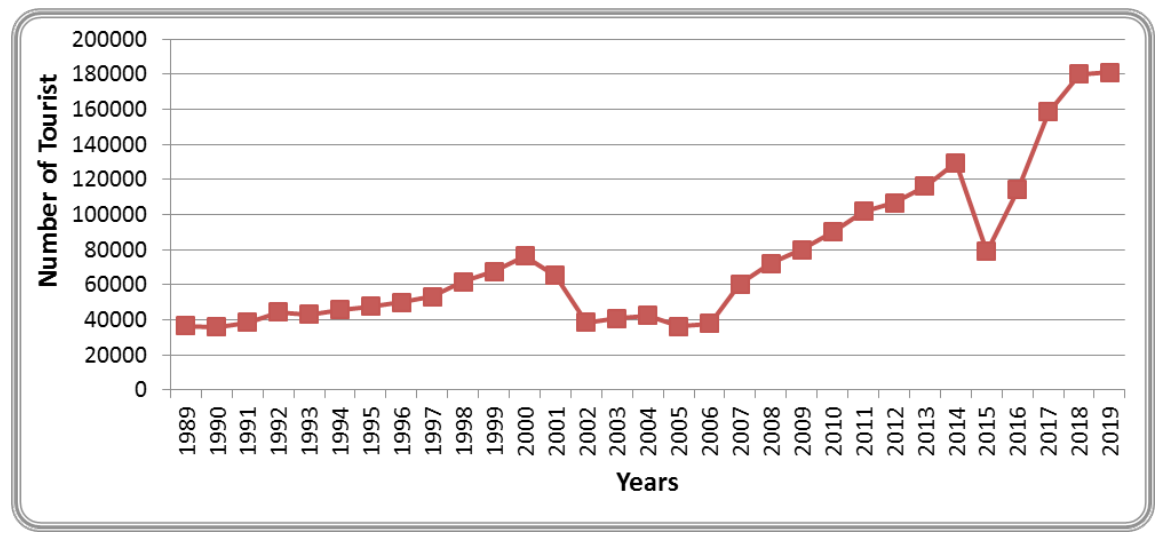

Figure 2: Tourist flow in Annapurna Conservation Area, 1989-2019

Source: ACAP Office, Pokhara, 2020. 
It can be clearly divided into three groups:

i) High increment years $\quad(>30 \%)-1991,1992,2007,2016 \& 2017$;

ii) Low increment years $(<30 \%)$ - 1994-2000, 2003-2004, 2006, 20082014, 2018 \& 2019; and

iii) Negative increment years- 1990, 1993, 2001, 2002, 2005 \& 2015.

The trend of tourist flow is found gradually increased from 1989 to 2000. Conversely, it was slightly decreased due to insurgency from 2001 to 2007. Thereafter, the number of tourists has been steadily increased up to 2014. Unfortunately, earthquake has brought devastation in Nepal in April and May 2015. The destruction caused by earthquake has greatly influenced tourist travel in ACA. The country had earned Rs 53.42 billion from tourism revenue in fiscal year 2014-15. The sharp drop in the revenue resulted from earthquake in April and May 2015. This situation has continuously worsened from India's trade block in Nepal. Fortunately, this situation has remained for a short period. The trekking tourism is being satisfactorily rejuvenated from 2016 to 2019 (Figure 2). Therefore, domestic as well as international tourists are gradually increasing around Annapurna range in recent years.

\section{DISASTER AND TOURISM}

The Inter-governmental Panel on Climate Change (IPCC), fourth assessment report mentions that the Himalaya, including Nepal, is a white spot, where scientific information on climate change is lacking. Certain parts of the world are suffering from natural disasters including: seismically and volcanically active areas, those subject to hurricane or tornardo, typhoon or tsunami, flood, avalanche, landslide, sudden frost or intense storms (Borrow 1997). Some land degradation is resulted due to natural (bio-geo-physical) causes; some is due to human causes and some due to a combination of both causes (Pradhan \& Pradhan 2006).

ACA is emerging as the nature based tourism area which is a major contributor to the economy of the local people. This high Himalayan region is an important destination for mountaineering visitors. The contribution of it to conservation is also significant. However, recently, trekking tourism is being subjected to multiple stressors. Natural disasters like snow avalanches, landslide and earthquake etc. have been influencing tourism sector. Despite this, increasing climate variability and other climatic changes are increasing 
the vulnerability of the place, people and their livelihood (Lama, 2010), and the local residents and environment have suffered a lot from this.

\section{Snow storm}

2014 has been deadliest year for Manang and Mustang districts in the history of mountaineering in Nepal when 25 people were killed, including 9 foreign visitors on 14 October. The Rescue Team of Nepal Army found 12 dead bodies and some injured trekkers from the Thorung La Pass on the Annapurna Circuit. The next avalanche swept away 5 climbers and 3 Nepali yak herders in upper Manang (Blair 2014). Likewise, the Rescue Team informed that 168 foreign visitors were registered to hike in Mustang and Manang districts (Kannampilly 2014). But, the Rescue Team was faced much difficulty to identify the actual location of snow storm affected tourists because of poor communication and infrastructure development.

Thousands of mountaineers have been visiting the Annapurna Circuit every year. According to Tourism Promotion Board of Nepal, a total of 101,320 trekkers visited Nepal in 2007. Out of them 59.4\% visited Annapurna area while those visiting the Everest and Langtang regions accounted for $26.5 \%$ and $8.1 \%$ respectively. October is favorable weather for mountain visit. It is the peak season for trekking. But the aftermath of Cyclone Hudhud the picture was changed in 2014. It has also affected Nepal's mountaineering industry that year. For example, 16 climbing Sherpas were killed after falling in ice avalanche in the Mount Everest a few months ago in the same year (18 April, 2014). A same icefall had taken place in 1970 as Mount Everest disaster (https://en.wikipedia. org/ ).

\section{Earthquake 2015}

Nepal has been adversely affected by the casualties, collapsed buildings and economic losses from the incidents of earthquake on 25 April and 12 May 2015. Various infrastructures including buildings and heritages have been severely damaged in 14 districts. The earthquake has destroyed about 2,900 structures of historical, cultural and religious heritage buildings. Seven major world heritage monuments were damaged and some of them have fallen down massively in the Kathmandu valley. Likewise, thousands of private traditional residence buildings, historical public buildings, ancient and recently built temples and monasteries were damaged, and around $25 \%$ of them were destroyed entirely in more than 
20 districts. The estimated cost of heritage damages was US\$ 169 million (NPC 2015).

Nepal is facing various disasters like landslide, flood, glacial lake outburst floods, rock fall, and avalanches particularly in high mountain areas (MoHA 2009 \& ICIMOD 2011). Now critical issues are raised for safety from visitors to monuments or buildings in the important heritage sites. Consequently, the number of tourist arrivals in Nepal has drastically declined by about $90 \%$ between May and July 2015. About 150 kilometers infrastructure of tourists' trekking trails were also destroyed; and trails of 200 kilometers need repair and maintenance in rural parts of the country (NPC 2015). Due to this, the tourist arrival has significantly reduced in mountain area. Tourist accommodations have either fully or partially been damaged in the Annapurna, Langtang, Khumbu, Manaslu, Jiri and Rolwaling areas. Ultimately, tourism sector has further failed to provide jobs in rural areas, and revenue of the country has been affected.

\section{Impact on livelihood}

Natural disaster has threatened our daily life. The people of Annapurna area are mostly influenced by snow storm and earthquake. It has also made impact on the livelihood of surrounding communities and natural environment. After the 2015 earthquake, trekking tourism of ACA has been significantly affected. According to ACAP Pokhara Office, altogether 129,624 trekkers had visited Annapurna region in 2014. However, the number of trekkers fell sharply to $39 \%(78,930)$ mainly due to a series of earthquakes shake in 2015 (NPC 2015). Similarly, Tourism Employment Survey, 2014 of the Ministry of Culture, Tourism and Civil Aviation (MoCTCA), Government of Nepal indicates that approximately 138,148 persons were engaged in the tourism sector while the WTTC 2015 report indicates that travel and tourism in Nepal have directly supported 487,500 jobs in pre-earthquake data in 2014. Earthquake 2015 affected the livelihood of about 2.29 million households and 5.6 million workers in all sectors of affected 31 districts of Nepal, resulting in the loss of 94 million work days and NPR 17 billion of personal income in fiscal year 2015-2016 (NPC 2015). Trekkers in the higher end segment are more likely to cancel their visits. Thus, the tourism sector appears to be most severely affected. It is estimated that 31.1 percent of all work days lost occurred in tourism. Despite this, major trekking destinations have provided 40,000 employees as guides, porters, cooks etc - who became jobless during May 
- July 2015. In the same line, 228 tour guides are no longer employed for their livelihood getting disconnected from their place of origin (NPC 2015). Likewise, Tourist activity in Nepal stimulates employment from formal businesses including international and domestic airlines, hotels, home stays and travel agencies which multiply income generating opportunities in the informal economy through the activities of some associated professionals, e.g., porters, minibus/ taxi operators as well as vendors who sell handicrafts and other goods to tourists.

It is estimated that the overall impact on the Nepali tourism industry is being hampered due to reduction of tourists' arrival annually. Physical infrastructures and human lost have been unexpectedly very high from various geo-hazards like avalanches and landslides in the Manang and Mustang area. But, there is a lack of precise information on the condition of accommodation buildings and trekking route in remote areas. The number is recorded high for Nepali tourism industry which has been targeting one million tourists since as early as 2011. Nevertheless, the earthquake of 2015 hit hard in tourist arrival that is gradually coming back on track. Tourism entrepreneurs are also hopeful of seeing rise in the number of tourists in the future.

\section{CONCLUSIONS}

Tourism has been growing as an alternative occupation of local communities in the Annapurna region. Mountain tourism has been given particular attention due to its attraction and complexity in the recent decades. Natural factors are also influencing the growth of tourism industry in our context. Nevertheless, Natural and human-induced disasters have been experienced all over the world. Meanwhile, Snow Storm 2014 and Earthquake 2015 have severely impacted in the ACA.

Annapurna Circuit has been favored for trekking route in the world. The trend of tourist flow has gradually increased from 1989 to 2000. But, it has slightly decreased due to Maoist's movement from 2001 to 2007. Thereafter, tourist flow to the country began to increase steadily up to 2014. Unfortunately, Snow avalanche in October 2014 and earthquake disasters in April and May 2015 have brought devastation in Nepal. Earthquake caused destruction has greatly influenced tourist travel in ACA. However, the number of trekkers fell sharply to 39\% in 2015 than figure of 2014 in Annapurna region. As a result, GDP and employment situation was found worsening. It is estimated that $31.1 \%$ of all work days lost occurred 
in tourism sector. It has also sharply dropped revenues. After natural devastation in the high mountain areas of Nepal, the major challenge is how local people can cope with their livelihood in unfavorable environment. Nonetheless, tourist arrival is gradually coming back on track from 2016 and onward. Annapurna region is expectantly returning back to continue as the popular trekking destination of Nepal.

\section{REFERENCES}

Bajracharya, S. B. (2009). Tourism development in Annapurna Conservation Area. In: Kruk, E.; Kreutszmann, H. and Richter, J. (eds.) Proceeding of the Regional Workshop: Integrated tourism concepts to contribute to sustainable mountain development in Nepal. GIZ, ICIMOD and BMZ, Kathmandu, pp. 127-142.

Bajracharya, S. B., Furley, P. A. \& Newton, A. C. (2006). Impacts of community-based conservation on local communities in the Annapurna Conservation Area, Nepal. Biodiversity and Conservation, 15: 2765-2786. https://doi.org/10.1007/s10531005-1343-x

Blair, D. (2014). Avalanches in Nepal kill 25, including 9 foreigners. www. telegraph.co.uk/, Accessed: 24.11.2017.

Borrow, C. J. (1997). Developing the environment- problems and management. Singapore: Longman.

CBS. (2012). National population and housing census 2011 - VDC/ municipality report. Kathmandu: Central Bureau of Statistics (CBS), National Planning Commission Secretariat, Government of Nepal.

DNPWC. (2018). Protected areas of Nepal. Kathmandu: Department of National Parks and Wildlife Conservation, Langtang National Park, Ministry of Forests and Soil Conservation, Government of Nepal.

DNPWC. (2010). Red Panda conservation action plan for Langtang National Park, Nepal. Kathmandu: Department of National Parks and Wildlife Conservation, Langtang National Park, Ministry of Forests and Soil Conservation, Government of Nepal.

IPCC. (2007). Climate change 2007: Impacts, adaptation and vulnerability. In: Parry, M.L., Canziani, O.F., Palutikof, J.P., Linden, P.J. V. D. and Hanson, C.E. (eds.). Contribution of working group II to the 
fourth assessment report of the intergovernmental panel on climate change. Cambridge: Cambridge University Press.

ICIMOD. (2011). Glacial lakes and glacial lake outburst floods in Nepal. ICIMOD, Kathmandu.

Kannampilly, A. (2014). Himalayan blizzard, avalanche kill 17 trekkers in Nepal. https://www.yahoo.com/, Accessed: 17.11.2017.

Lama, A. k. (2010). Vulnerability of nature based tourism to climate change: Stakeholders' perceptions of and response to climate change in the lower Mustang region of the Annapurna Conservation Area (Unpublished Master thesis), Parks, Recreation and Tourism Management, Lincoln University, New Zealand.

Miyamoto, H. K. \& Gilani, A. SJ. (2017). Damage assessment and seismic retrofit of traditional and modern midrise buildings in the aftermath of 2015 Nepal earthquake. 16th World Conference on Earthquake, Santiago Chile. https://www.earthquakeengineeringtechnicalpapers. com/, Accessed: 08.07.2020.

MoCTCA \& Miyamoto. (2015). Damage assessment of Annapurna region Nepal. Government of Nepal through the Ministry of Culture, Tourism and Civil Aviation and Miyamoto Earthquake Structural Engineer. https://miyamotointernational.com/, Accessed: 08.07.2020.

MoCTCA. (2016). Nepal tourism statistics 2015. Ministry of Culture, Tourism \& Civil Aviation, Planning and Evaluation Division, Statistics and Research Section, Government of Nepal, Singha Durbar, Kathmandu.

MoHA \& DPNet. (2009). Nepal disaster report: The hazardscape and vulnerability. Ministry of Home Affairs, Government of Nepal and Disaster Preparedness Network, Kathmandu.

MoHA \& ICIMOD. (2015). A preliminary assessment of potential lower Pisang landslides dam outburst flood. Ministry of Home Affairs, Government of Nepal, Utrecht University NASA, USGS, CAS and ICIMOD. https://www.icimod.org/, Accessed: 20.05.2015.

Nepal, S.K. (2000). Tourism in protected areas: The Nepalese Himalaya. Annals of Tourism Research, 27(3): 661-681. https://doi. org/10.1016/S0160-7383(99)00105-X 
NPC. (2015). Nepal earthquake post-disaster needs assessment (PDNA) report. National Planning Commission, Government of Nepal, Kathmandu.

NTNC. (2009). Management plan of Annapurna conservation area (2009- 2012). National Trust for Nature Conservation (NTNC), Khumaltar, Lalitpur and Annapurna Conservation Area Project (ACAP), Pokhara, Nepal.

NTNC. (2017). Annapurna conservation area management plan (20172021). National Trust for Nature Conservation (NTNC) and Conservation Development Foundation, Khumaltar, Lalitpur, Nepal.

Practical Action. (2009). Temporal and Spatial Variability of Climate Change Over Nepal (1976-2005). Kathmandu : Practical Action Nepal Office.

Pradhan, P. K. \& Pradhan, B. (2006). Environment and natural resources: Concepts, methods, planning \& management. Kathmandu: Quest publication.

Sharma, P. (2012). Tourism in Nepal 2030. In: Sharma SR, Upreti BR and Pyakuryal K (eds.), Nepal 2030: A vision for peaceful and prosperous nation, Kathmandu: South Asia Regional Coordination Office of the Swiss National Centre of Competence in Research (NCCR North-South) and Department of Development Studies, Kathmandu University, pp 73-92.

Shrestha, H. P. \& Shrestha, P. (2012). Tourism in Nepal: A historical perspective and present trend of development. Himalayan Journal of Sociology \& Anthropology, 5: 54-75.

Wells, M. P. (1994). Parks tourism in Nepal: Reconciling the social and economic opportunities with the ecological and cultural threats. In: Munasinghe, M \& McNeely, J. A. (eds.) Protected Area Economic and Policy: Linking Conservation and Sustainable Development, The World Bank, Washington DC, pp 319-331, https://portals.iucn. org/, Accessed: 12.06.2020.

Wikipedia. (n. d.). 2014 Mount Everest ice avalanche. https://en.wikipedia. org/, Accessed: 04.04.2020.

WTO. (2018). UNWTO tourism highlights, 2018 edition. United Nations World Tourism Organization, Madrid. https://doi. org/10.18111/9789284419876 
WTTC. (2018a). Travel and tourism global economic impact \& issues 2018. World Travel \& Tourism Council (WTTC). United Kingdom, London. https://dossierturismo.files.wordpress.com/, Accessed: 29.07.2018.

WTTC. (2018b). Travel and tourism economic impact- 2018, South Asia. World Travel \& Tourism Council (WTTC). United Kingdom, London. https://wttc.org/, Accessed: 28.07.2018.

WWF NEPAL. (2013). Hariyo Ban Program, Chitwan-Annapurna Landscape, A Rapid Assessment. Kathmandu: WWF Nepal, Hariyo Ban Program. 